\title{
1. Development theories, old and new and their implications for human rights $^{1}$
}

\section{Balakrishnan Rajagopal}

The current world economic, ecological and political crises, deepened by the COVID-19 pandemic, reveal a profound challenge to conventional thinking on human rights and development. Human rights, primarily economic and social rights, are based on a theory of constant expansion of the economic pie for all, and development is explicitly predicated on the idea of the nation-state leading the ever-increasing process of economic and social wellbeing of its citizens through international cooperation and solidarity. These assumptions have never been more challenged than now: perpetual world economic expansion is under threat; the real wealth of the world - not just the economic wealth - may be shrinking rather than expanding; economic and social wellbeing is increasingly undermined for the most vulnerable populations of the world suffering from a global pandemic. The role of the nation-state is increasingly contested as a vehicle for development as autocratic and populist regimes question and withdraw from traditional tools of development cooperation, leaving the international community more divided than ever.

The challenge of determining who is accountable for these worsening outcomes and who will be responsible for ensuring a different and more sustainable future are central questions of this chapter. These challenges are not only national and international, but also sub-state and within social systems in constant interaction. The transformation of global governance calls for more than simply international governance; it is a matter of "global governance", that is, the arena beyond or outside the state and "governance" as

\footnotetext{
1 Parts of this chapter appeared in Balakrishnan Rajagopal, "Counter-hegemonic International Law: Rethinking Human Rights and Development as a Third World Strategy" Third World Quarterly 27, no. 5 (2006): 767-83; Balakrishnan Rajagopal, "Right to Development and Global Governance" Human Rights Quarterly 35, no. 4 (2013): 893-909; and Olivier De Schutter and Balakrishnan Rajagopal (eds), Property Rights from Below: Commodification of Land and the Counter-Movement (London: Routledge, 2020).
} 
a one-dimensional exercise of authority rather than an interactive one among layers of decision-making. This chapter will analyze the inherited challenges of global governance to the realization of development and the implications for human rights. I will begin with a critique of development theories and review the emergence of a non-hegemonic global south.

\section{OLD AND NEW DEVELOPMENT THEORY}

The most difficult challenge for contextualizing human rights and development is the one posed by the crisis of development theory and the models of human rights, especially economic and social rights, now revealed most clearly in the form of the global health and economic crisis of the COVID-19 pandemic. Development theory has a long history going back to classical and neoclassical economics, Keynesian economics and neoliberalism, structural functionalism and sociological modernization theory, as well as critical theories of development, drawing on Marxism, socialism, and Third World or Global South approaches to international relations.

The debate over the development theory in the 1980s was characterized by the double sense that developing countries were deprived of the fruits of modern technology and economic and social progress due to the unjustified and oppressive policies of the rich countries, and that development was unfair in process and outcome to the rights of individuals and communities within states. Ergo, the reasoning went, development should be expanded, countries should grow economically, and the standard of living for everyone must go up to catch up with the best of the West. However, this catching-up rationale had an insidious and self-defeating logic to it. So long as the planet can sustain economic growth, endless growth is indeed possible. But that assumes that the real costs of economic development and globalization, in human and environmental terms, can be fully accounted for, assessed when they go too far, and mitigated before crisis becomes catastrophe. The barriers to such honest accounting and response are well known by now - the myopia of expertise and specialization, the narrow professionalism of the ruling class, the lack of ethical regard for the values of human solidarity, and the self-serving exploitation of the weak and of the planet's resources. Under these circumstances, it is hard to see how theory can rely on an ever-expanding notion of development, material progress, and standard of living. Instead, it is necessary to think of an approach to "development" within limits, both natural and ethical, to the industrial and globalizing model, unlike the limitless model dominant today and in the past.

The 2020 global health and economic crisis is only a symptom of deeper underlying malaise. It is a crisis of development itself, not just of growth, but of the broader idea that a constant improvement in living standards and even 
happiness is possible through technology, science, and rational thought, and that development is realized through an increase in wealth. The basic idea that the crisis is due to mistakes committed by a few "bad apples" - as was claimed following the 2008 financial crisis - or the pandemic - overlooks the root of the problem. Rather, it has to do, borrowing from Joseph Schumpeter, with a process that I will call "destructive creation". Schumpeter, of course, is famous for his theory of "creative destruction" to describe the process of economic innovation in capitalism which destroys old structures and creates new ones and would, he argued, eventually lead to capitalism's demise. ${ }^{2}$ I want to flip this over - following a more accurate Marxist reading of creative destruction by David Harvey and others - to say that, in fact, the development process is more accurately described as destructive creation. ${ }^{3}$ To create anything of value, it needs to destroy what existed before; in relying on the idea of scarcity, which is at the heart of economic theory, the process of development in fact leads to a ceaseless accumulation, consumption and destruction of resources. ${ }^{4}$ Every act of creation of value in the economy now involves more destruction than creation. Following this reasoning, the current economic crisis is structural and not exceptional.

The crisis indicates that the model of economic development and globalization which is dominant today is based on a process of destructive creation, which is not morally, economically, or environmentally sustainable. A search for alternatives must begin by critiquing these foundational assumptions, which permeate the legal, social, political, and cultural orders which defend development and globalization. As Immanuel Wallerstein asked recently: "[A]fter development and globalization, what?"5 There is a broad recognition of the inherent limits of an economic model which is based on scarcity, unending accumulation, and consumption instead of human wellbeing and happiness. There are signals coming from stressed civilizations and a stressed planet that the path we are on is unsustainable.

2 See Joseph Schumpeter, Capitalism, Socialism and Democracy (New York: Harper \& Row, 3d ed. 1962).

3 David Harvey, "Neoliberalism as Creative Destruction" The Annals of the American Academy of Political and Social Science 610 (2007): 22-44.

4 Balakrishnan Rajagopal, "International Law and the Development Encounter: Violence and Resistance at the Margins," 93rd Am. Soc'y Int'l L. Proc. 16 (1999). See also Leslie Sklair, "Social Movements and Global Capitalism" in The Cultures of Globalization (Frederic Jameson and Masao Miyoshi eds., Durham: Duke University Press, 1998) (articulating a critique of what he calls the "culture-ideology of consumerism". Ibid at 302).

5 Immanuel Wallerstein, “After Development and Globalization, What?" 83 Soc. Forces 1263 (2005). 


\section{THE TRAGEDY OF THE COMMONS}

If we go back to the 1960s, the prevailing view was that of the developmentalists, who believed that users of natural resources would behave as rational economic agents, driven by a short-term urge to increase their revenue and to maximize their individual utility. The concept of the "tragedy of the commons" reflected this pessimism about the viability of shared resources. ${ }^{6}$ Since the 1990s however, a large number of studies have demonstrated that, under certain conditions, local communities are capable of managing common resources and might even do so in ways that are more sustainable and more effective than if such management were left either to individual owners following a process of privatization or to the state. These communities, after all, are ideally positioned to design the governance system that is best suited to the local conditions. In such cases, members of the community will normally perceive the rules they set as highly legitimate. Since community members will have contributed to shaping the governance regime, they are likely to have a strong incentive in contributing to the enforcement of the rules. And to a large extent, as the rules will be designed with a view to improving the situation of the community as a whole rather than that of individual members, they may be shaped in order to minimize negative externalities and to preserve the long-term viability of the resource, thus improving sustainability. These ideas were popularized in 1990 in a book-length publication based on the studies done by Elinor Ostrom and her collaborators on the management of common-pool resources ${ }^{7}$ and followed by later contributions illustrating the fecundity of the hypothesis. ${ }^{8}$

At the heart of these approaches is the idea that individuals should not be seen as locked into a setting in which competition for the use of the resource is inevitable. Instead, provided the right institutional conditions are present, individuals can move toward cooperative solutions. Whereas the management of natural resources is generally seen through the paradigm of the Prisoner's Dilemma, in which selfish rational behavior by each individual can only lead

\footnotetext{
6 See Garrett Hardin, “The Tragedy of the Commons” Science 162 (3859), (1968) 1243-48.

7 Elinor Ostrom, Governing the Commons: The Evolution of Institutions for Collective Action (New York: Cambridge University Press, 1990).

8 See, for instance, Bina Agarwal, "Participatory Exclusions, Community Forest, and Gender: An Analysis for South Asia and Conceptual Framework" World Development 29 (2001), 1623-48; Robert M. Cox, Elizabeth U. Parker, Diane M. Cheney, Andrea L. Liebl, Lynn B. Martin and Ryan Calsbeek, "Experimental Evidence for Physiological Costs Underlying the Trade-off between Reproduction and Survival" Functional Ecology 24, no. 6 (2010): 1262-69.
} 
to collectively sub-optimal solutions (justifying therefore the imposition of top-down regulations to force efficient outcomes). If given the opportunity to set their own rules, communities may be able to act better (more efficiently, more legitimately and more sustainably) than the state, whereas others have argued for instance, "the prisoners in the famous dilemma cannot change the constraints imposed on them by the district attorney". ${ }^{9}$

\section{EMERGENCE OF A COUNTER-HEGEMONIC GLOBAL SOUTH}

The category "Third World" is no longer just a collection of states united by ideology, economic development, and a shared sense of historic wrongs, but is instead a fragmented idea with a hegemonic and a counter-hegemonic frame. ${ }^{10}$ Indeed, the transition from Third World to Global South is indicative of this fragmentation and reorientation. It is by now the case that the Third World is a collection of social movements and collective mobilizations of workers, peasants, farmers, urban poor, women, indigenous peoples and many others who do not benefit from the insertion of the Third World into the global economy or who bear the costs of insertion disproportionately. Globalization and the resultant circulation of capital, technology, culture and manufacturing have decreased Western domination of capital and technology, even as it persists in the formal structures of international economic and political governance which continue to be dominated by them. The rise of new contenders to power, especially China and the other "BRICS" (Brazil, Russia, India, China, and South Africa), has posed new questions of power and accountability unlike those faced in the 1980s and 1990s. In particular, the very same forces that enabled medium and large developing countries to exploit globalization have also revealed in the first decades of the $21^{\text {st }}$ century serious fissures in the solidarity of developing countries, and have given rise to new challenges of global governance. The emergence of the BRICS remains embedded in, or intertwined with, states and statist structures such as the UN, and states and statist structures have themselves become an arena of contestation between hegemonic and counter-hegemonic social forces.

9 Mancur Olson, The Logic of Collective Action: Public Goods and the Theory of Groups (Harvard Economic Studies v. 124. Cambridge, Mass.: Harvard University Press, 1971).

10 Balakrishnan Rajagopal, "Counter-Hegemonic International Law: Rethinking Human Rights and Development as a Third World Strategy" Third World Quarterly 27 (2006): 767; Balakrishnan Rajagopal, International Law from Below: Development, Social Movements and Third World Resistance (Cambridge: Cambridge University Press, 2003) 219-30. 
The rise of counter-hegemonic and hegemonic forces in the Third World poses serious challenges to global governance but also an opportunity to reinvent itself. The challenges posed by global social movements to global governance are indicated by the motto of the World Social Forum: "Another World is Possible". ${ }^{11}$

In this approach, social movements seek to be both modern and different, and not caught up in the binary of modernity versus tradition. The challenge that they pose is one of epistemology and ethics as they seek to problematize the superiority of expert knowledge, the overreliance on professionalism, the over-bureaucratization of social life, the pervasiveness of power and its tendency to corrupt, and the possibilities inherent in collective action and solidarity. Many of these challenges are, as noted over a dozen years ago, ${ }^{12}$ the ones identified by current analysts of global governance as key to the understanding of today's world and of the possible ways to govern it better. From development theory perspective, these challenges reveal the limits of its current framing but also show ways in which it can be made more relevant to the counter-hegemonic global south. It is no secret that the framing of development theory, including such concepts as the right to development discussed elsewhere in this book, ${ }^{13}$ has not had a significant impact as a tool of struggle or activism in the human rights field, but rather has remained esoteric at the level of geopolitics of the nation-states. This can be contrasted to the way other human rights, including economic and social rights, are deployed in struggles around the world. It is partly this failure to "connect" with the real politics of human rights that has kept development theory weak. The radical potential in it can be unleashed well if it links creatively with the politics of the counter-hegemonic South.

\section{TRANSFORMATIVE GEOPOLITICS OF HUMAN RIGHTS AND DEVELOPMENT}

Many scholars and practitioners believe that, in the light of our experience with development and globalization, human rights violations are often essential for the production and reproduction of wealth and productivity in the economic sense. In this view, the violation of human rights is often part and parcel of

11 See Peter Waterman and Jai Sen, World Social Forum: Challenging Empires (Montreal: Black Rose Books, 2d ed. 2009); Boaventura de Sousa Santos, The Rise of the Global Left: The World Social Forum and Beyond (London: NBN International, 2008).

12 See David Kennedy, "The Mystery of Global Governance" 34 Ohio N. U. L. Rev. (2008): 827, 842-45.

13 See chapter 16. 
what we call successful development or globalization. Such a view maintains that in fact it is not the denial of development or the exclusion from globalization that causes human rights violations and economic and social deprivation in general, but rather that the misery of the poor is in fact a "planned misery", as Susan Marks called it a decade ago. ${ }^{14}$

If we start from the premise that globalization is essentially benign in its impact on the weak and subalterns, and that the problem is one of lack of adequate insertion of the poor into global markets, circuits of capital, and culture, then the reform of global governance yields one set of proposals that may include the further democratization of international organizations by increasing the voice of developing countries in their governance, increasing the participation of civil society in global governance, and imposing and enforcing obligations against private entities and so on. However, if we start from the premise that globalization is a problematic project because it has a structural bias against the weak, the poor, and the vulnerable - one which is hard to separate from its logic of production, consumption and distribution - we must then address a different set of reform proposals regarding global governance. Such reforms may be more far-reaching and fundamental than any which are currently on the global agenda. They might include fundamental changes to the way markets, finance and governance are organized at multiple levels and call for sharp augmentation of the capacity for solidarity, collective action and self-governance.

Indeed, a shift from government to governance has been one of the signal shifts of the post-Cold War consolidation of neoliberal democracy on a global scale. ${ }^{15}$ This shift, which occurred in the literature in international relations, is distinct from, but related to, the shift to the language of governance in new governance theory ${ }^{16}$ as well as to "good governance" in the development field. ${ }^{17}$

14 See Susan Marks, "Human Rights and Roots Causes" 74 Mod. L. Rev. 57 (2011). There is a long line of thinking and writing that echoes this across several disciplines, most recently captured through the post-development critique.

15 See James N. Rosenau and Ernst Otto Czempiel, Governance without Government: Order and Change in World Politics (Cambridge: Cambridge University Press, 1992).

16 The literature is vast. See, e.g., Bob Jessop, "The Rise of Governance and the Risks of Failure: The Case of Economic Development” 50 Int'l Soc. Sci. J. 29 (1998); Orly Lobel, "The Renew Deal: The Fall of Regulation and the Rise of Governance in Contemporary Legal Thought" 89 Minn. L. Rev. 342 (2004).

17 See, e.g., World Bank, "World Development Report: Building Institutions for Markets" 5 (2002); International Monetary Fund (IMF), "Good Governance: The IMF's Role" (1997); World Bank, "Governance: The World Bank's Experience” (1994); United Nations Development Programme (UNDP), "Reconceptualising Governance" (1997); Daniel Kaufmann et al., "Governance Matters: From Measurement to Action" 
The common ground between the first two senses of the term "governance" is that a government-centered regulatory approach to effectiveness and legitimacy of functioning social and economic systems is no longer adequate. This is due to many reasons, including the rise of non-state actors, networks among them, their ability to act in situations where conventional state-based action seemed to be lacking, as well as the absence of supranational systems of order. But at a deep normative level, the governance focus was too often parasitic on the good governance agenda, which articulated an ideal vision of what the limits of state action ought to be. ${ }^{18}$ It was postulated that such an approach must emphasize deregulation, privatization, public-private partnerships, decentralization, democratization (often procedural), human rights (often thin versions) and transparency. The problems of this ideal vision have, during the last two decades, become apparent, and in many respects, it has been abandoned in practice. This is not the place to discuss these problems at length, but it can be noted that the good governance agenda served to undermine the development potential of robust state action while disciplining the populations using a highly limited and hypocritical deployment of human rights and democracy. ${ }^{19}$ Robust state action is now, once again, recognized as central to development success ${ }^{20}$ while the need to ensure the accountability of states through human rights and democracy is also well recognized. Where one or the other is missing, it has produced undesirable and often violent social consequences. The recent rise of global protests and instability is a consequence.

An approach to global governance must begin by clarifying what one means by governance, and in particular, whether or not it is related to good governance with its anti-Third World government ideology. A global governance

37 Fin. \& Dev. 2 (June 2000); Merilee Grindle, "Good Enough Governance Revisited" 25 Dev. Pol'y Rev. 553 (2007).

18 This is not often recognized. For an attempt to recognize the distinct deployment of the term "governance" that nevertheless does not make this link, see Thomas G. Weiss, "Governance, Good Governance and Global Governance: Conceptual and Actual Challenges" 21 Third World Q.795 (2000).

19 See, e.g., James Gathii, "Good Governance as a Counter Insurgency Agenda to Oppositional and Transformative Social Projects in International Law" 5 Buff. Hum. Rts. L. Rev. 107 (1999).

20 The heterodox literature that processes this point is by now vast, starting with Gerschenkron, and extends through Amsden, Chang, and Rodrik. See Alexander Gerschenkron, Economic Backwardness in Historical Perspective: A Book of Essays (Cambridge, Mass.: Harvard University Press, 1962); Alice Amsden, The Rise of the "Rest": Challenges to the West from Late Industrializing Economies (Oxford Scholarship Online, 2003); Ha-Joon Chang, Kicking Away the Ladder: Development Strategy in Historical Perspective (New York: Anthem Press, 2002); Dani Rodrik, "Why Do More Open Economies Have Bigger Governments?" 106 J. Pol. Econ. 997 (1998). 
agenda is doomed to fail if it is grounded in the idea of disciplining states and celebrating private actors while failing to recognize the centrality of states for positive economic and social outcomes, or if it celebrates a narrow understanding of development while sacrificing accountability of state and private actors. Rather, the challenge we face is the need for a global governance agenda that reinstates accountable and embedded statehood as part of the solution, while committing itself to deep democratic structural transformation of such states, private networks, and supranational systems of order, and the creation and strengthening of norms and structures to hold states and other actors accountable to their commitments.

The rise of counter-hegemonic and hegemonic forces in the Third World poses serious challenges of global governance but is also an opportunity to reinvent itself. As noted already, the challenges posed by global social movements to global governance are indicated by the motto of the World Social Forum: "Another World is Possible". ${ }^{21}$ In this approach, social movements seek to be both modern and different, and not caught up in the binary of modernity versus tradition, as noted earlier. The challenge that they pose is one of epistemology and ethics as they seek to problematize the superiority of expert knowledge, the overreliance on professionalism, the over-bureaucratization of social life, the pervasiveness of power and its tendency to corrupt, and the possibilities inherent in collective action and solidarity. Many of these challenges are, as noted above, the ones identified by current analysts of global governance as key to the understanding of today's world and of the possible ways to govern it better. From a right to development perspective, these challenges reveal the limits of its current framing but also show ways in which it can be made more relevant to the counter-hegemonic global south. It is no secret that the right to development framing has not had a significant impact as a tool of struggle or activism in the human rights field, but rather has remained esoteric at the level of geopolitics of the nation-states. This can be contrasted to the way other human rights, including economic and social rights, are deployed in struggles around the world. It is partly this failure to "connect" with the real politics of human rights that has kept the right to development weak. The radical potential in it can be unleashed well if it links creatively with the politics of the counter-hegemonic South.

\section{CONCLUSION}

Counter-hegemonic thinking has shattered many shibboleths in world politics, international law and human rights even as it confirmed the centrality of

21 See $n 11$. 
many others. It tried to shift the focus of development, which had remained nation-state centered in legal terms, to individuals and communities; it posited an ethic of solidarity as a soft legal obligation, giving substance to Article 28 of the UDHR; ${ }^{22}$ it reinforced the centrality of participation in the development process as a key to making it better; it articulated the Gandhian idea that the purpose of development was the fulfillment of human personality; and it fulfilled the geopolitical needs of a frustrated Third World coalition at the UN which had seen its demand for a new international economic order ignored by the West. Despite these impressive achievements, development theory remained disconnected from the real politics of human rights, which arose from the struggles of social movements; it gave ideological cover to a sovereigntist approach to development, which actually ignored human rights, and most importantly, it remained wedded to a vision of development and human rights without limits.

The 2008 global economic crisis and the current economic upheaval resulting from the COVID-19 pandemic are only symptoms of deeper underlying malaise. It is a crisis of development itself - not just of growth, but of the broader idea that a constant improvement in living standards and even happiness is possible through technology, science and rational thought, and that development is realized through an increase in wealth. The basic idea that the crisis is due to mistakes committed by a few "bad apples" - Lehman Brothers, or overleveraged banks, or spendthrift Greeks or Irish or of the Chinese or American failure to prevent and mitigate the spread of a pandemic virus - is a mistaken understanding of the root of the problem. Rather, it has to do borrowing from Joseph Schumpeter - with a process that I call "destructive creation" as noted before. Schumpeter, of course, is famous for his theory of "creative destruction" to describe the process of economic innovation in capitalism which destroys old structures and creates new ones and would, he argued, eventually lead to capitalism's demise. ${ }^{23}$ As I argued before, I want to flip this over - following a more accurate Marxist reading of creative destruction by David Harvey and others - to say that, in fact, the development process is more accurately described as destructive creation. ${ }^{24}$ To create anything of value, it needs to destroy what existed before; in relying on the idea of scarcity - which is at the heart of economic theory - the process of development in fact

22 Universal Declaration of Human Rights, adopted 10 Dec. 1948, G.A. Res. 217A (III), U.N. GAOR, 3d Sess, art. 28, U.N. Doc. A/RES/3/217A (1948) states: "Everyone is entitled to a social and international order in which the rights and freedoms set forth in this Declaration can be fully realized."

23 See $n 2$.

24 See David Harvey, "Neoliberalism as Creative Destruction" 610 Annals Am. Acad. Pol. \& Soc. Sci. 22 (2007). 
leads to a ceaseless accumulation, consumption, and destruction of resources. ${ }^{25}$ Every act of creation of value in the economy now involves more destruction than creation. Following this reasoning, the current economic crisis is structural and not exceptional.

The global pandemic of 2020, like the economic crisis of 2008, reveals most clearly the problems with these dimensions of development, even if it highlights the need to recover the more progressive elements of human rights thinking. The stakes of global governance for achieving such a progressive vision of human rights and development have never been higher.

25 For an earlier attempt to argue along the same lines that the idea of scarcity drives much of legal imagination in international law and human rights and why this is unsustainable, see Balakrishnan Rajagopal, "International Law and the Development Encounter: Violence and Resistance at the Margins" 93rd Am. Soc'y Int'1 L. Proc. 16 (1999). See also Leslie Sklair, "Social Movements and Global Capitalism" in The Cultures of Globalization (Frederic Jameson \& Masao Miyoshi eds., Durham: Duke University Press, 1998). He has articulated a critique of what he calls the "culture-ideology of consumerism". Ibid at 302. 